\title{
Studi Perencanaan Turbin Air PLTMH di Sungai Cilaki
}

\author{
Maridjo, Slameto, Deyfan Satria Wibawa, Ahmad Lutfy \\ Jurusan Teknik Konversi Energi, Politeknik Negeri Bandung, Indonesia \\ Email: mmaridjo1@gmail.com
}

\begin{abstract}
Penelitian ini bertujuan untuk mengetahui potensi Sungai Cisitu di Garut apabila digunakan sebagai pembangkit listrik tenaga mikro hidro. Potensi yang diteliti meliputi: seberapa besar debit yang tersedia; mengetahui tinggi jatuh efektif efektif yang tersedia; mengetahui seberapa besar potensi daya listrik yang dapat dihasilkan dengan menggunakan PLTMH. Penelitian ini diawali dengan studi pustaka,untuk mengetahui hubungan head dan debit terhadap jenis turbin. Dilanjutkan studi potensi hidrolik ini berkaitan dengan lokasi wilayah DAS sungai Cilaki. Tahap berikutnya yaitu survey lapangan, untuk mendapatkan data lapangan. Hasil penelitian diperoleh head sebesar $60 \mathrm{~m}$ dan debit sebesar 2,33 m3/s. Berdasar Head dan debit yang diperoleh, jenis turbin yang digunakan adalah turbin Francis. Hasil rancangan dimensi turbin memiliki diameter keluaran runner (D3) sebesar 0,5772 m, diameter masukan runner (D1) sebesar 0,4690 m, lebar keluaran runner (H2) sebesar 0,2016 m dan lebar masukan runner (H1) sebesar 0,1431 m. Jumlah sudu pengarah yaitu sebanyak 12 buah dan diameter poros sebesar 95,75 mm. Daya poros yang dihasilkan sebsar 1090,56kW pada putaran $1000 \mathrm{rpm}$.
\end{abstract}

\section{Kata Kunci studi, potensi hidrolik, turbin air}

\section{PENDAHULUAN}

Pembangkit Listrik Tenaga Mikro Hidro (PLTMH) merupakan alternatif sumber energi listrik bagi masyarakat, PLTMH memberikan banyak keuntungan terutama bagi masyarakat pedesaan di seluruh Indonesia. Disaat sumber energi lain mulai menipis dan memberikan dampak negatif, maka air menjadi sumber energi yang sangat penting karena dapat dijadikan sumber energi pembangkit listrik yang murah dan tidak menimbulkan polusi. Potensi sumber daya air ini terdapat banyak di Indonesia, terutama didaerah yang memiliki sungai yang memiliki head yang cukup.

Daerah Garut memiliki banyak sungai yang berpotensi untuk menghasilkan energi listrik. Ini sesuai dengan KebijakanEnergi Nasional, yang tertuang dalam Peraturan Pemerintah Nomor 79 Tahun 2014 tentang pemanfaatan sumber daya energi nasional yang diarahkan untuk ketenagalistrikan salah satunya adalah sebagai sumber energi terbarukan dari jenis energi aliran dan terjunan air [1].

Sungai Cilaki merupakan salah satu sungai yang memiliki potensi yang diperkirakan dapat dikembangkan untuk menghasilkan energi listrik. Untuk itu perlu studi lapangan untuk mengetahui seberapa besar potensi energi listrik yang dihasilkan. Jaringan PLN didaerah Garut juga sudah tersedia, tetapi untuk daerah pedesaan terpencil masih terbatas, masih banyak daerah yang belum mendapatkan aliran listrik. Dengan kondisi yang demikian, maka usaha pemanfaatan air untuk menghasilkan energi listrik amat diperlukan.

Banyak penelitian terdahulu telah dibuat seperti oleh Suparyawan dkk, Ikrar Hanggara dkk, Sri Sukamta dkk. Penelitian terdahulu hanya membahas mengenai studi potensi airnya, hubungan head, debit dan potensi listrik yang dibangkitkan.

Pada penelitian ini, akan dilakukan selain mengkaji studi potensi air; akan dikaji juga saluran air yang dibutuhkan; penelitian juga mengkaji turbin air yang cocok digunakan, dan desain turbin airnya. Diharapkan penelitian ini nanti dapat ditindaklanjuti dengan pembangunannya. Listrik yang dihasilkan nanti diharapkan akan dapat memenuhi kebutuhan listrik didaerah tersebut, dengan demikian akan dapat meningkatkan kesejahteraan masyarakat sekitarnya.

\section{TINJAUAN PUSTAKA}

Pengembangan kapasitas pembangkit tenaga listrik diarahkan untuk memenuhi pertumbuhan beban, dan pada beberapa wilayah tertentu diutamakan untuk memenuhi kekurangan pasokan tenaga listrik. Berdasarkan Peraturan Pemerintah Nomor 79 Tahun 2014 tentang KebijakanEnergi Nasional, pemanfaatan sumber daya energi nasional yang diarahkan untuk ketenagalistrikan salah satunya adalah sebagai sumber energi terbarukan dari jenis energi aliran dan terjunan air [1].

Potensi tenaga air di Indonesia menurut Hydro Power Potential Study (HPPS) pada tahun 1983 adalah 75.000 MW 1). Potensi air sebesar itu tentunya akan sangat bermanfaat bila dapat direalisasikan, maka perlu studi rinci di setiap daerah yang memiliki potensi pengembangan pembangkit tenaga listrik.

1. Pengertian PLTMH [2][3]

Pembangkit Listrik Tenaga Mikrohidro (PLTMH), biasa disebut mikrohidro, adalah suatu pembangkit listrik skala kecil yang menggunakan tenaga air sebagai penggeraknya, misalnya dari saluran irigasi, sungai atau air terjun alam, dengan cara memanfaatkan tinggi terjunnya (head, dalam meter) dan jumlah debit airnya (m3/detik). Umumnya PLTMH yang dibangun, jenis run off river dimana head diperoleh tidak dengan membangun bendungan besar, melainkan dengan mengalihkan aliran air sungai ke satu sisi dari sungai dan menjatuhkannya lagi ke sungai pada suatu tempat dimana beda tinggi yang diperlukan sudah diperoleh. Dengan menggunakan pipa, air dialirkan ke power house (rumah pembangkit) yang biasanya dibangun di pinggir sungai. Melalui guide vane air akan dialirkan keluar memutar roda turbin (runner), kemudian air tersebut dikembalikan ke sungai asalnya. Energi mekanik putaran poros turbin akan diubah menjadi energi listrik oleh sebuah generator.

Pembangkit listrik tenaga air dibawah ukuran kecil digolongkan sebagai PLTMH (Pembangkit Listrik Tenaka Mikrohidro). Dalam perencanaan pembangunan sebuah PLTMH, diperlukan 
pengetahuan tentang hidrologi, permesinan, kelistrikan dan bangunan sipil.

2. Komponen-komponen Pembangkit Listrik Tenaga Mikrohidro [3]

Komponen komponen suatu PLTMH yaitu:

a.Intake

Intake berfungsi menampung aliran air dan mengarahkan ke turbin.

b. Bak Pengendap

Bak pengendap digunakan untuk memindahkan partikelpartikel pasir dari air. Fungsi dari bak pengendap adalah sangat penting untuk melindungi komponen-komponen berikutnya dari dampak pasir.

c. Saluran pembawa

Saluran pembawa ini berfungsi mengalirkan air dari bendung. Saluran pembawa mengikuti kontur dari sisi bukit untuk menjaga elevasi dari air yang disalurkan. Pada saluran yang panjang perlu dilengkapi dengan saluran pelimpah. Fungsi saluran pelimpah ini untuk menjaga jika terjadi banjir maka kelebihan air akan terbuang melalui saluran tersebut.

d. Bak penenang

Fungsi dari bak penenang adalah untuk menenangkan air yang akan masuk turbin melalui penstock.

e. Pipa pesat

Pipa pesat berfungsi untuk mengubah energi potensial air di bak penenang menjadi energi kinetik air.

f. Rumah turbin

Tempat peletakan turbin dan generator

g. Turbin

Berfungsi mengubah energi potensial air menjadi energi mekanik dalam bentuk putaran poros

h. Generator listrik

Berfungsi merubah energi mekanik poros menjadi energi



3. Energi potensi air

Suatu PLTMH memerlukan head dan aliran air untuk menghasilkan tenaga yang bermanfaat. Beberapa penelitian perencanaan pembangkit sudah dilakukan seperti:

Suparyawan dkk, Jurnal Teknik Elektro, Vol. 12 No. 2 Juli Desember 2013, meneliti Studi Perencanaan Pembangkit Listrik Mikrohidro di desa Sambangan menyatakan bahwa Perancangan PLTMH Baru menggunakan debit desain sebesar 0,623 m3/s dan head $18 \mathrm{~m}$, akan diperoleh potensi listriknya adalah 82,42 kW [4]

Ikrar Hanggara dkk, Jurnal Reka Buana Volume 2 No 2, Maret 2017 - Agustus 2017 meneliti Potensi PLTMH di Desa Jombok Kecamatan Ngantang Kabupaten Malang, diperoleh Besar debit (Q) pengukuran langsung di lokasi studi yaitu Desa Jombok yaitu $0.95 \mathrm{~m} 3 / \mathrm{dt}$, Head berdasarkan pengukuran lapangan adalah Desa Jombok sebesar 5 meter, diperoleh daya sekitar $46.60 \mathrm{KW}$. [5]
Sri Sukamta dkk., Jurnal Teknik Elektro Vol. 5 No. 2 Juli Desember 2013, studi Perencanaan Pembangkit ListrikTenaga Mikro Hidro (PLTMH) Jantur Tabalas Kalimantan Timur, Hasil yang diperoleh debit air (Q) di sungai mencapai 323 liter/detik, serta tinggi jatuh air $15 \mathrm{~m}$ dan aliran air melalui pipa menuju ruang turbin sebesar 274,55 liter/detik. PLTMH yang direncanakan menghasilkan daya sebesar $40 \mathrm{KW}$ (6)

Dari beberapa penelitian diatas, dapat diambil kesimpulan bahwa besar debit dan head yang berbeda beda di daerah yang berbeda dapat dihasilkan daya yang cukup memadai untuk kebutuhan listrik pedesaan. Head dan debit yang berbeda beda ini tentunya juga akan berdampak pada pemilihan turbin airnya.

Untuk menentukan head dan debit yang tepat perlu dilakukan tahapan berikut yaitu analisis hidrologi dan dilanjutkan dengan perencanaan hidromekanikal

4. Pemilihan jenis turbin [2] [3]

Pemilihan sebuah turbin air yang baik tergantung pada:

- Head yang tersedia

- Debit air yang tersedia

Kisaran penggunaan dari setiap tipe turbin ditunjukan dalam gambar2, dibawah ini.

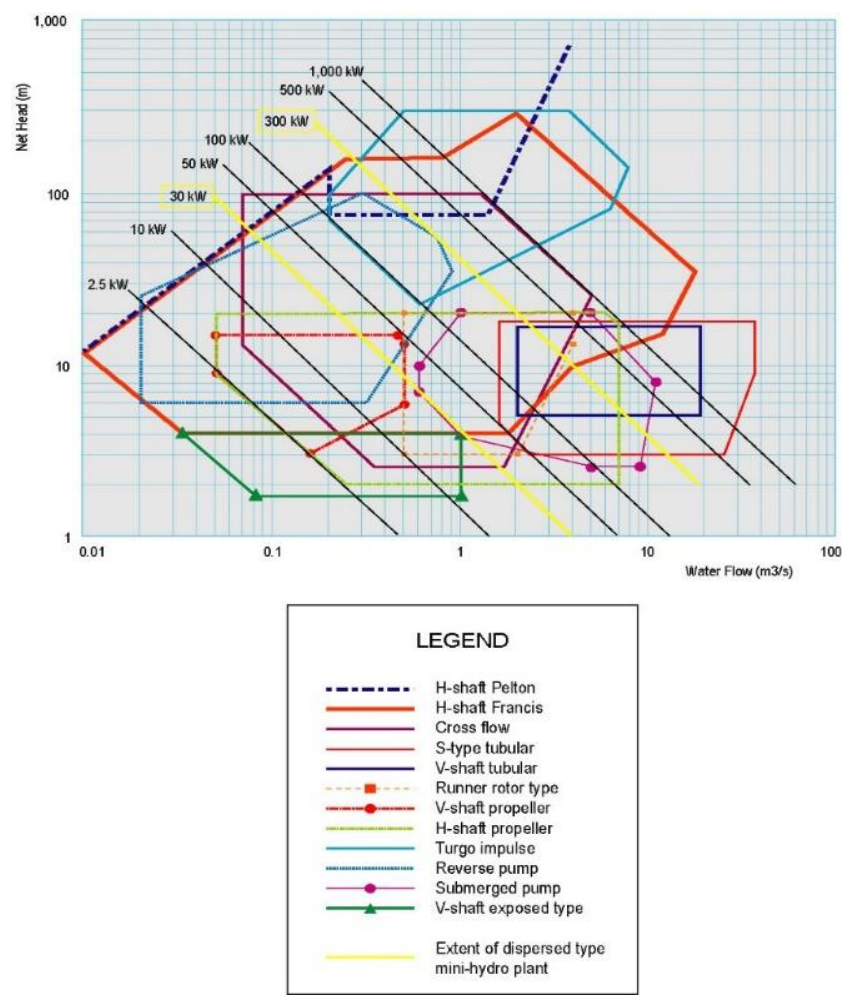

Gambar II.2 Bagan pemilihan jenis turbin

Output dari turbin dapat dihitung dengan rumus berikut: [3] [7] $P=\rho \times g \times H e \times Q \times \eta t$

Dimana P: $\quad$ output maksimum $(\mathrm{kW})$

He: head efektif (m)

Q: $\quad$ debit (m3/s)

$\rho: \quad$ massa jenis air $[\mathrm{kg} / \mathrm{m} 3]$

g: $\quad$ Percepatan gravitasi [m/s2]

$\eta \mathrm{t}: \quad$ efisiensi maksimum turbin $(\%)$

$\mathrm{He}=\mathrm{Hb}-(\mathrm{Hl}+\mathrm{Hm})$

Dimana Hb: Head brutto

Hl: Head losses mayor

$$
=f \times \frac{L}{D} \times \frac{v^{2}}{2 g} \mathrm{~m}
$$


m: Head losses minor

$$
=\frac{k \mathrm{X} v^{2}}{2 \mathrm{X} g} \mathrm{~m}
$$

4. Kecepatan spesifik juga dapat digunakan untuk menentukan jenis turbin.

Kecepatan spesifik ini menunjukkan bentuk dari turbin. Kecepatan spesifik turbin menunjukkan titik efisiensi maksimumnya. Menentukan kecepatan spesifik suatu turbin digunakan rumus berikut:

$N_{S}=n \frac{\sqrt{P}}{H^{5 / 4}}$

Keterangan:

$\mathrm{Ns}=$ Putaran spesifik turbin (rpm)

$\mathrm{n}=$ Putaran poros turbin (rpm)

$\mathrm{P}=$ Daya turbin $(\mathrm{HP})$

$\mathrm{H}=\operatorname{Head}(\mathrm{m})$

$N q=n \times \frac{\sqrt{Q}}{H^{0,75}}$

Keterangan:

$$
\begin{aligned}
& \mathrm{n}=\text { Putaran poros yang direncanakan }(\mathrm{rpm}) \\
& \mathrm{Q}=\text { Debit air }(\mathrm{m} 3 / \text { detik }) \\
& \mathrm{H}=\text { Head }(\mathrm{m})
\end{aligned}
$$

5. Perancangan turbin air [7]

a. Diameter poros

Persamaan yang digunakan untuk menentukan perkiraan awal dari diameter poros turbin dinyatakan dalam persamaan berikut:

Dsh $=\sqrt[3]{\frac{5,1 \times K_{1} \times C_{b} \times T}{\tau_{a}}}$

b Segitiga kecepatan turbin air

Segitiga kecepatan merupakan dasar kinematika dari aliran air. Segitiga kecepatan dapat dicari dengan menggunakan kecepatan spesifik dan beberapa data dari gambar grafik berikut ini:

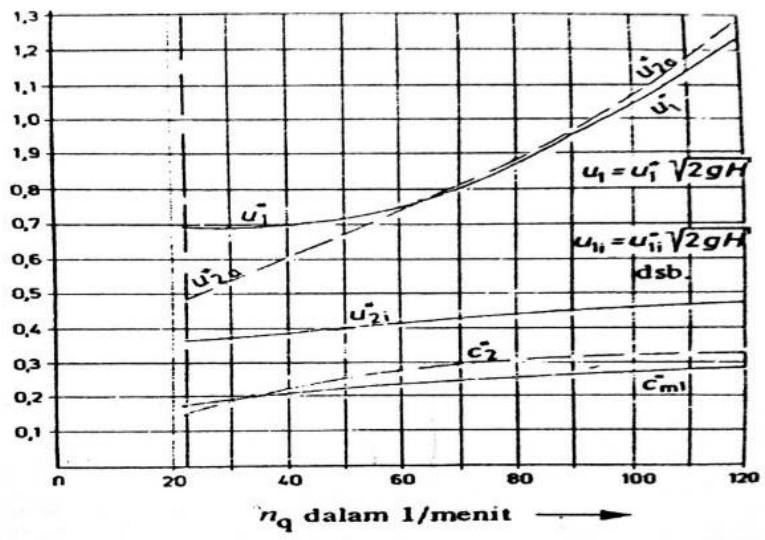

Gambar II.3 Grafik parameter awal untuk menentukan segitiga kecepatan c. Penentuan runner turbin

Penentuan dimensi turbin untuk memberikan gambaran baik instalasi maupun peralatan penunjang turbin'

Perhitungan dimensi runner turbin menggunakan persamaan berikut ini:

$$
\begin{aligned}
& \mathrm{D} 3=(26,2+0,211 \mathrm{Ns}) \frac{\sqrt{h_{e f}}}{n}, \\
& \mathrm{D} 1=\left(0,4+\frac{94,5}{N_{s}}\right) \times \mathrm{D} 3, \\
& \mathrm{D} 2=\frac{1}{\left(0,96+0,000386 N_{s}\right)} \times \mathrm{D} 3, \\
& \mathrm{H} 2=\left(-0,05+\frac{42}{N_{s}}\right) \times \mathrm{D} 3 » » »(50<\mathrm{Ns}<110) \\
& \left.\mathrm{H} 2=\frac{1}{\left(3,16-0,0013 N_{s}\right)} \times \mathrm{D} 3 » »\right)((110<\mathrm{Ns}<350)
\end{aligned}
$$

\section{d. Lebar runner}

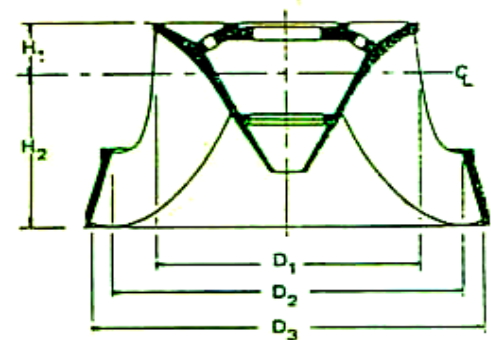

Gambar II.4 Skema Runner Turbin

Lebar runner merupakan lebar masukan air menuju runner, untuk menentukan besar lebar dari runner digunakan grafik perbandingan lebar runner dengan diameter masukan central streamline (D2) sebagai fungsi dari putaran spesifik (Ns), adapun grafik tersebut dapat dilihat pada gambar di bawah ini:

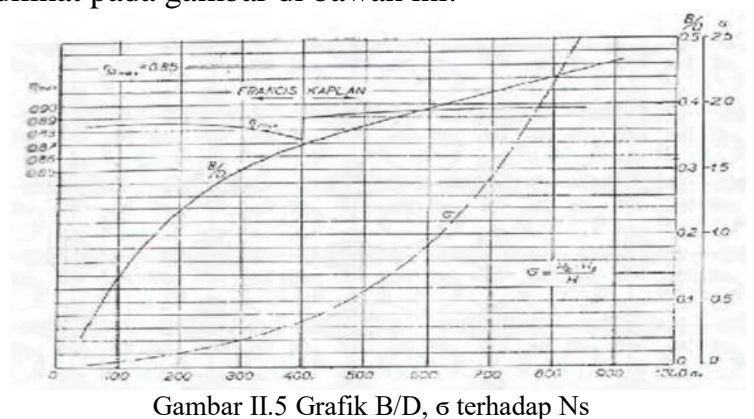

e. Sudu pengarah

Gambar II.5 Grafik B/D, 6 terhadap Ns

Sudu pengarah berfungsi sebagai pengarah air dari rumah turbin menuju sudu jalan, dan juga berfungsi sebagai distributor agar air disekeliling sudu jalan mempunyai debit yang sama rata,

1) Diameter pengarah

Diameter sudu pengarah ditentukan dengan menggunakan rumus dibawah ini:

$\mathrm{D}=\frac{60 \times \mathrm{K} \times \sqrt{2 \mathrm{gH}}}{\pi \times \mathrm{N}}$

2). Tinggi sudu pengarah

Penentuan tinggi sudu pengarah menggunakan rumus berikut ini:

$$
\mathrm{b}=\frac{\mathrm{Q}}{\pi \times \text { Do } \times \mathrm{ku} \times \sqrt{2 \mathrm{gH}}}
$$

3). Panjang sudu pengarah

Panjang sudu pengarah ditentukan oleh persamaan berikut :

$\mathrm{L} \approx 0,3$ Do

4). Jumlah sudu pengarah

Jumlah sudu pengarahtergantung pada diameter dan kecepatan spesifik turbin

5) Rumah turbin

Penentuan nilai dari dimensi rumah turbindiperoleh dari persamaan berikut

$\mathrm{A}=\left(1,2-\frac{19,5}{N_{S}}\right) \times \mathrm{D} 3$,

$\mathrm{B}=\left(1,1+\frac{54,8}{N_{s}}\right) \times \mathrm{D} 3,(16) \mathrm{C}=\left(1,32+\frac{49,25}{N_{s}}\right) \times \mathrm{D} 3$,

$\mathrm{D}=\left(1,50+\frac{48,8}{N_{s}}\right) \times \mathrm{D} 3$,

$\mathrm{E}=\left(0,98+\frac{63,6}{N_{s}}\right) \times \mathrm{D} 3$,

$\mathrm{F}=\left(1+\frac{131,4}{N_{s}}\right) \times \mathrm{D} 3$,

$\mathrm{G}=\left(0,89+\frac{96,5}{N_{s}}\right) \times \mathrm{D} 3$,

$\mathrm{H}=\left(0,79+\frac{81,75}{N_{s}}\right) \times \mathrm{D} 3$,

$\mathrm{I}=(0,1+0,00065 \mathrm{Ns}) \times \mathrm{D} 3$,

$\mathrm{L}=(0,88+0,00049 \mathrm{Ns}) \times \mathrm{D} 3$,

$\mathrm{M}=(0,60+0,000015 \mathrm{Ns}) \times \mathrm{D} 3$ 


\section{METODE PENELITIAN}

Penelitian ini diawali dengan studi pustaka. Studi pustaka ini diharapkan dapat diketahui jenis turbin yang tepat untuk berbagai head dan debit yang berbeda. Bagaimana menentukan dimensi turbin air berdasar potensi yang tersedia. Studi potensi hidrolik ini berkaitan dengan Lokasi Studi. seperti wilayah DAS sungai Cilaki. Tahap berikutnya yaitu survey lapangan, untuk mendapatkan data lapangan.

Tahapan survey lapangan. Tahapan dalam studi merencanakan Pembangkit Listrik Tenaga Mikro Hidro (PLTMH) di sungai Cilaki Garut adalah sebagai berikut:

a.Analisa Peta Topografi. Peta topografi digunakan sebagai dasar untuk perencanaan / desain bangunan PLTMH pada lokasi yang terpilih dan head PLTMH.

b.Analisa Hidrologi [3]. Analisis hidrologi digunakan untuk menentukan debit. Data data diatas diambil dari peta topografi dengan menggunakan aplikasi Google Earth dan debit. Penentuan debit dengan menggunakan Metode FDC (Flow Duration Curve). Perhitungan FDC dengan menggunakan data curah hujan dan data klimatologi yang tersedia.

c. Perencanaan konstruksi hidromekanikal.

\section{HASIL DAN PEMBAHASAN}

Hasil survey dan pembahasan sebagai berikut:

1.Identifikasi lokasi survei awal yaitu lokasi penelitian.

Daerah penelitian terletak di Sungai Cilaki, Kecamatan Talegong, Kabupaten Garut, Propinsi Jawa Barat. Secara geografis wilayah penelitian terletak pada koordinat antara $7^{\circ} 18^{\prime} 28.99^{\prime \prime S}, 107^{\circ} 31^{\prime} 6.93 "$. Jarak tempuh sekitar 3 jam melalui jalan darat.

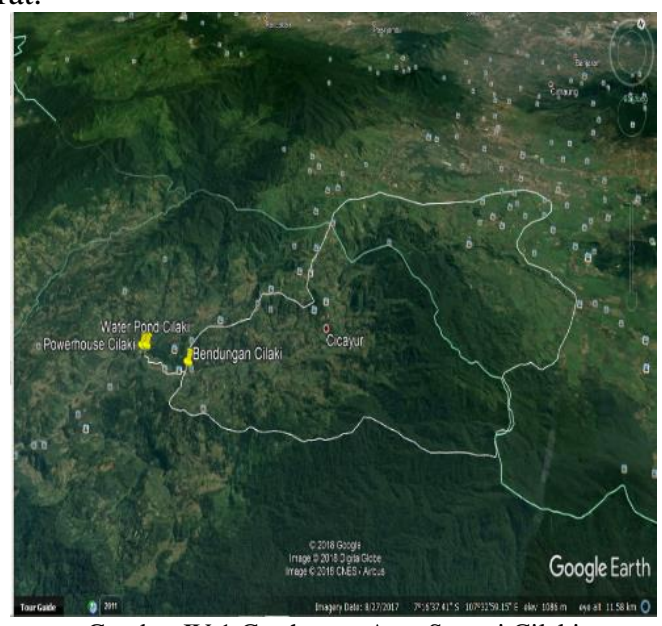

Gambar IV.1 Catchment Area Sungai Cilaki

Layout PLTMH ditentukan menggunakan Google earth.

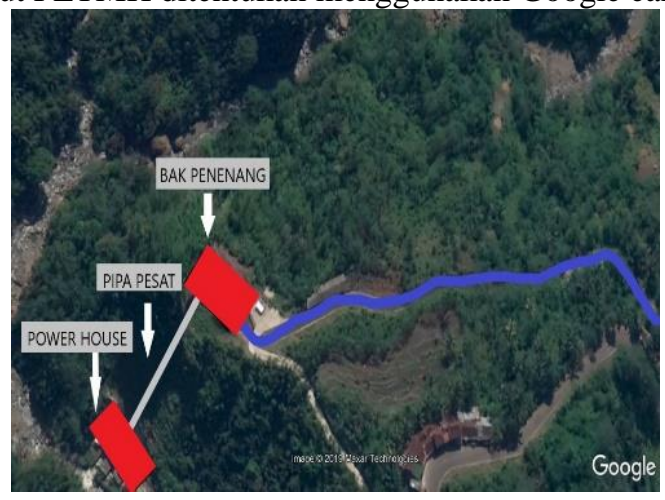

Gambar IV.2 Lay out komponen PLTMH
Dari lay out PLTMH ini dapat ditentukan head PLTHH. Perbedaan ketinggian antara bak penenang dan power house diperoleh sebesar $64 \mathrm{~m}$.

2.Perhitungan Debit Andalan Menggunakan Metode FDC (Flow Duration Curve). FDC dibuat berdasarkan data debit yang tercatat pada Sungai Cilaki selama 5 tahun dari tahun 2008 sampai dengan tahun 2012. Tabel hasil perhitungan FDC untuk masing-masing tahun dapat dilihat pada Tabel IV.1.

Tabel IV.1 Data Debit Tahun 2008-2012

\begin{tabular}{|c|c|c|c|c|c|c|c|}
\hline \multirow[t]{3}{*}{ Tahun } & \multicolumn{7}{|c|}{ Bulan } \\
\hline & Jan & Feb & Mar & Apr & May & Jun & Jul \\
\hline & Aug & Sep & Oct & Nov & Dec & & \\
\hline \multirow[t]{2}{*}{2008} & 4.24 & 3.88 & 5.09 & 5.65 & 3.03 & 3.99 & 1.74 \\
\hline & 1.11 & 0.87 & 7.93 & 7.29 & 4.61 & & \\
\hline \multirow[t]{2}{*}{2009} & 6.22 & 7.87 & 8.75 & 6.25 & 3.71 & 2.55 & 2.29 \\
\hline & 1.52 & 1.34 & 2.16 & 2.75 & 1.92 & & \\
\hline \multirow[t]{2}{*}{2010} & 4.40 & 7.04 & 8.66 & 6.15 & 3.43 & 4.56 & 3.77 \\
\hline & 2.94 & 3.14 & 2.91 & 3.30 & 3.47 & & \\
\hline \multirow[t]{2}{*}{2011} & 3.81 & 4.59 & 4.70 & 3.94 & 1.54 & 2.73 & 2.23 \\
\hline & 1.31 & 1.63 & 1.31 & 2.59 & 3.62 & & \\
\hline \multirow[t]{2}{*}{2012} & 3.21 & 2.95 & 3.09 & 3.32 & 3.13 & 3.00 & 3.00 \\
\hline & 1.71 & 1.58 & 1.37 & 2.00 & 2.63 & & \\
\hline \multirow[t]{2}{*}{ Rata2 } & 4.38 & 5.27 & 6.06 & 5.06 & 2.97 & 3.37 & 2.61 \\
\hline & 1.72 & 1.71 & 3.14 & 3.59 & 3.25 & & \\
\hline
\end{tabular}

Data debit tersebut ditabulasikan berdasarkan besaran debit pada masing-masing probabilitas. Selanjutnya diplotkan ke dalam bentuk grafik perbandingan antara besaran debit terhadap probabilitas kejadian/ketersediaan yang disebut dengan grafik durasi aliran (Flow Duration Curve/FDC). Grafik FDC dapat dilihat pada Gambar IV.3, dibawah.

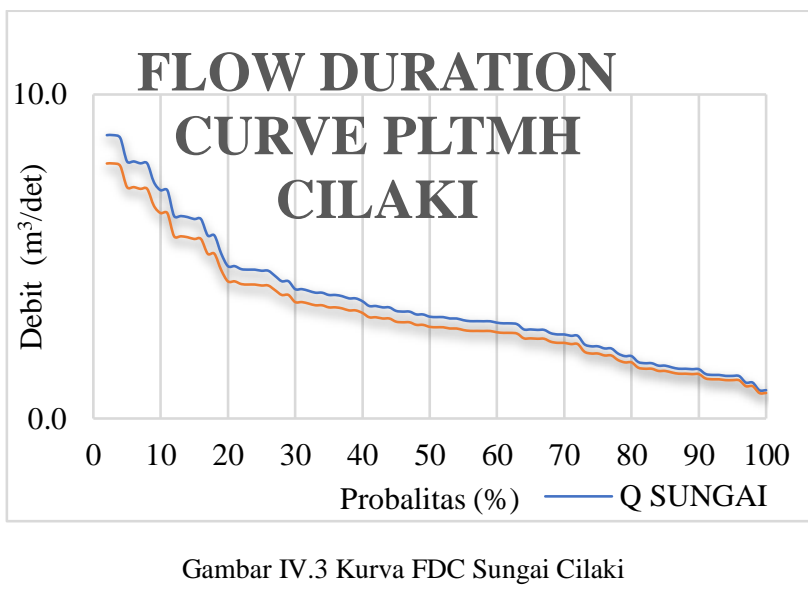

Berdasarkan grafik diatas dapat ditentukan probabilitas $10 \%$, $20 \%, 30 \%, 40 \%, 50 \%, 60 \%, 70 \%, 80 \%, 90 \%$, dan $100 \%$ dapat dilihat di Tabel di bawah. Dengan data Flow Duration Curve (FDC) tersebut dapat dibuat FDC untuk PLTMH Sungai Cilaki. 
Tabel IV.1 Flow Duration Curve Sungai Cilaki berdasarkan probabilitas

\begin{tabular}{|c|c|c|c|c|c|}
\hline $\begin{array}{l}\text { Proba } \\
\text { bilitas } \\
(\%)\end{array}$ & $\begin{array}{l}\text { Q PLTM } \\
\text { (m³/det) }\end{array}$ & $\begin{array}{l}\text { Flow } \\
\text { (\%) }\end{array}$ & $\begin{array}{l}\text { N Turbin } \\
\text { Francis } \\
\text { (\%) }\end{array}$ & $\begin{array}{l}\text { Daya } \\
(\mathrm{Kw})\end{array}$ & $\begin{array}{l}\text { Energi } \\
\text { (Mwh) }\end{array}$ \\
\hline 5 & 7,14 & 100 & 80 & 3355,837007 & 1469,856609 \\
\hline 10 & 6,34 & 100 & 80 & 2978,969067 & 2609,576903 \\
\hline 15 & 5,54 & 100 & 80 & 2603,031882 & 3420,383892 \\
\hline 20 & 4,23 & 100 & 80 & 1988,952893 & 3484,645468 \\
\hline 25 & 4,10 & 100 & 80 & 1928,454004 & 4223,314268 \\
\hline 30 & 3,59 & 100 & 80 & 1688,507786 & 4437,398461 \\
\hline 35 & 3,43 & 100 & 80 & 1612,06665 & 4942,596347 \\
\hline 40 & 3,26 & 100 & 80 & 1530,596745 & 5363,210995 \\
\hline 45 & 2,99 & 100 & 80 & 1403,946982 & 5534,359003 \\
\hline 50 & 2,83 & 100 & 80 & 1328,941907 & 5820,765551 \\
\hline 55 & 2,73 & 100 & 80 & 1283,03163 & 6181,646393 \\
\hline 60 & 2,66 & 100 & 80 & 1249,784953 & 6568,869711 \\
\hline 65 & 2,47 & 100 & 80 & 1162,342857 & 6618,380229 \\
\hline 70 & 2,33 & 100 & 80 & 1096,974199 & 6726,64579 \\
\hline 75 & 2,00 & 85.84 & 88 & 1036,433289 & 6485,111152 \\
\hline 80 & 1,73 & 74.25 & 90 & 915,3450975 & 6414,738443 \\
\hline 85 & 1,47 & 63.09 & 91 & 784,571853 & 5841,922017 \\
\hline 90 & 1,37 & 58.80 & 91 & 732,1366937 & 5772,165693 \\
\hline 95 & 1,18 & 50.64 & 93 & 646,4305807 & 5379,595293 \\
\hline 100 & 0,79 & 33.91 & 44 & 203,1165907 & 1779,301335 \\
\hline
\end{tabular}

Dari tabel Flow Duration Curve dari Sungai Cilaki diatas, dipilih probabilitas $70 \%$ yaitu dengan debit desain sebesar 2,33 $\mathrm{m} 3 / \mathrm{s}$ karena turbin tidak akan $100 \%$ beroperasi selama 1 tahun sebab turbin mememrlukan perawatan dan batas operasi aman dari turbin francis ialah diatas $40 \%$ dari debit desain. Apabila debit dibawah $40 \%$ maka yang terjadi air yang masuk kedalam turbin akan masuk dengan udara, hal ini sangat tidak diijinkan karena akan menyebabkan penurunan performansi turbin. Dipilih debit optimal yaitu $2,33 \mathrm{~m} 3 / \mathrm{s}$ pada probabilitas kejadian $70 \%$ karena memiliki energi yang dihasilkan paling besar

Putaran turbin dipilih $1000 \mathrm{rpm}$, mengikuti putaran mesin generator yang tersedia dipasaran.

Dari head dan Q diperoleh potensi daya turbin

$$
\begin{gathered}
\text { Daya Turbin }=998 \mathrm{~kg} / \mathrm{m}^{3} \times 9,81 \mathrm{~m} / \mathrm{s}^{2} \times 2,33 \mathrm{~m}^{3} / \mathrm{s} \times 60 \mathrm{~m} \times 0,8 \\
=1090,567 \mathrm{~kW}=1462,72 \mathrm{HP}
\end{gathered}
$$

\section{Pemilihan Jenis Turbin}

Pemilihan jenis turbin berdasarkan dari nilai head atau tinggi jatuh air dan debit yang akan dirancang yaitu dengan head sebesar $60 \mathrm{~m}$ dan debit 2,33 m3/dt. Pemilihan jenis turbin menggunakan gambar 10 yang bersumber dari buku (Guide on How To Develop a Small Hydropower Plant Part 2).

Dari gambar tersebut didapat bahwa turbin yang dapat digunakan yaitu turbin Francis

\section{Kecepatan Spesifik Turbin}

Kecepatan spesifik turbin digunakan untuk menentukan pemilihan turbin yang akan digunakan dalam perancangan dan juga untuk mencari nilai kecepatan putaran turbin. Kecepatan Spesifik dapat dicari menggunakan persamaan sebagai berikut :

$$
\begin{aligned}
& N_{S}=n \frac{\sqrt{P}}{H^{5 / 4}} \quad=1000 \frac{\sqrt{1472,472}}{60^{5 / 4}}=229,01 \\
& N q=\frac{n \sqrt{\text { Qdesign }^{2}}}{\text { Hnett }^{0,75}}=\frac{1000 \sqrt{2,33}}{60^{0,75}}=70,8 \mathrm{~L} / \text { menit }
\end{aligned}
$$

\section{Dimensi turbin}

Penentuan dimensi turbin dilakukan untuk mengetahui gambaran seberapa besar power house yang akan dibangun. Adapun komponen yang akan dilakukan perhitungan adalah runner, housing turbine, sudu pengarah, poros turbin.

a. Perancangan Poros

Pertama melakukan perhitungan dari diameter poros $\left(D_{s h}\right)$ didasarkan pada daya turbin yang ditransmisikan (N) sebesar 1090,567 kW, putaran turbin (n) $1000 \mathrm{rpm}$, dan menggunakan standar JIG G 4103 (SNCM25) yang memiliki kekuatan tarik bahan $\left(\tau_{\mathrm{b}}\right)=120 \mathrm{~kg} / \mathrm{mm}^{2}$. Momen puntir yang terjadi pada poros dapat ditentukan dengan persamaan di bawah ini:

$$
\begin{aligned}
\mathrm{T} & =9,74 \times 10^{5} \frac{\mathrm{N}}{\mathrm{n}} \quad=9,74 \times 10^{5} \frac{1090,567}{1000} \\
& =1019894,88 \mathrm{~kg} . \mathrm{mm}
\end{aligned}
$$

Untuk tegangan geser yang diijinkan dapat ditentukan dengan persamaan berikut:

$\tau_{\mathrm{a}}=\frac{\tau_{b}}{s f_{1} \times s f_{2}}$

dengan:

$s f_{1}$ : faktor keamanan untuk bahan $\mathrm{S}-\mathrm{C}=6$

$s f_{2}$ : faktor keamanan bentuk poros $1,3-3,0$

$\tau_{\mathrm{a}}=\frac{120}{6 \times 1,5}$

$=13,33 \mathrm{~kg} / \mathrm{mm}^{2}$

Sehingga diameter poros perkiraan awal adalah dapat ditentukan dengan persamaan dimana faktor koreksi terhadap beban tumbuk $\left(\mathrm{K}_{1}\right)=1,5-3$ dan faktor koreksi terhadap beban lentur $\left(\mathrm{C}_{\mathrm{b}}\right)=1,2-$ 2,3:

$$
\begin{aligned}
D_{\text {sh }} & =\sqrt[3]{\frac{5,1 \times 1,5 \times 1,5 \times 1019894,88}{13,33}} \\
& =95,75 \mathrm{~mm}=3,74 \mathrm{in}=4 \mathrm{in}
\end{aligned}
$$

Bahwa standar material yang dipilih tepat dibuktikan antar tegangan geser yang terjadi $(\tau)$ dengan tegangan geser yang diijinkan $\left(\tau_{\mathrm{a}}\right)$ dimana tegangan geser yang terjadi dimana ukuran dari poros yang digunakan sebesar 4 in $=101,6 \mathrm{~mm}$, maka:

$$
\begin{aligned}
\tau & =\frac{5,1 T}{D_{\text {sh }}^{3}} \\
& =\frac{5,1(1019894,88)}{101,6^{3}} \\
& =4,96 \mathrm{~kg} / \mathrm{mm}^{2}
\end{aligned}
$$

Maka dapat dilihat bahwa $\tau<\tau_{\mathrm{a}}$, dengan demikian bahan yang dipilih serta dimensi yang dirancang sudah memenuhi standar aman poros.

b. Segitiga Kecepatan Turbin Francis

Dari kecepatan spesifik $(\mathrm{Nq}=70,8 \mathrm{~L} /$ menit $)$ didapat parameter awal yang didapat sebagai berikut:

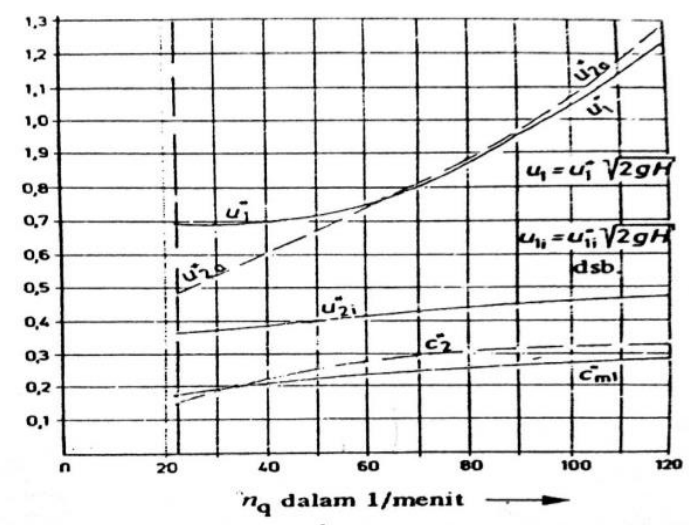

Gambar IV.5 Grafik parameter awal untuk menentukan segitiga kecepatan

$\mathrm{V}=\sqrt{2 x \text { gxHnett }}=\sqrt{2 \times 9,81 \times 60}=34,31 \mathrm{~m} / \mathrm{s}$ 
Sehingga didapat parameter awal untuk menentukan dimensi turbin sebagai berikut:

1) $U_{1}{ }^{*}=0,8 ; U_{1}=U_{1}{ }^{*} \times V=0,8 \times 34,31=27,448 \mathrm{~m} / \mathrm{s}$

2) $\mathrm{Cm}_{1}{ }^{*}=0,25 ; \mathrm{Cm}_{1}=\mathrm{Cm}_{1}{ }^{*} \times \mathrm{V}=0,25 \times 34,31=8,577 \mathrm{~m} / \mathrm{s}$

3) $U_{2 i}{ }^{*}=0,42 ; U_{2 i}=U_{21}{ }^{*} \times V=0,42 \times 34,31=14,410 \mathrm{~m} / \mathrm{s}$

4) $U_{2 a}{ }^{*}=0,81 ; U_{2 a}=U_{2 a}{ }^{*} x V=0,81 \times 34,31=27,791 \mathrm{~m} / \mathrm{s}$

5) $C_{2}{ }^{*}=0,3 ; C 2=C_{2}{ }^{*} \times V=0,3 \times 34,31=10,293 \mathrm{~m} / \mathrm{s}$

Dari parameter yang sudah ada, harus memenuhi persamaan Euler sebagai berikut:

Пturbin $\times \mathrm{g} \times \mathrm{Hnett}=\mathrm{U}_{1} \times \mathrm{Cu}_{1}-\mathrm{U}_{2} \mathrm{Cu}_{2}$

Pada pengeluaran yang tegak lurus kedalam pipa hisap, maka $\mathrm{Cu}_{2}=0$ dan $\alpha_{2}=90^{\circ}$

Sehingga persamaan euler menjadi:

クturbin $\times \mathrm{g} \times \mathrm{Hnett}=\mathrm{U}_{1} \times \mathrm{Cu}_{1}$

$\mathrm{Cu}_{1}=\frac{\eta \text { turbin } \times \mathrm{g} \times \mathrm{Hnett}}{\mathrm{U}_{1}}=\frac{0,8 \times 9,81 \times 60}{27,448}=18,227 \mathrm{~m} / \mathrm{s}$

Sehingga didapat segitiga kecepatan masuk pada turbin sebagai berikut:

1) $\mathrm{C}_{1}=\sqrt{C U_{1}{ }^{2}+C m_{1}{ }^{2}}=\sqrt{18,227^{2}+8,577^{2}}=20,144 \mathrm{~m} / \mathrm{s}$

2) $\mathrm{W}_{1}=\sqrt{\left(U_{1}-C U_{1}\right)^{2}+C m_{1}{ }^{2}}=$

$\sqrt{(27,448-18,227)^{2}+8,577^{2}}=12,593 \mathrm{~m} / \mathrm{s}$

3) $\alpha_{1}=\operatorname{Cos}^{-1} \frac{C U_{1}}{C_{1}}=\operatorname{Cos}^{-1} \frac{18,227}{20,144}=25,198^{\circ}$

4) $\beta_{1}=\operatorname{Cos}^{-1} \frac{U_{1}-C U_{1}}{W_{1}}=\operatorname{Cos}^{-1} \frac{27,448-18,227}{12,593}=42,926^{\circ}$

Berikut gambar segitiga kecepatan masuknya:

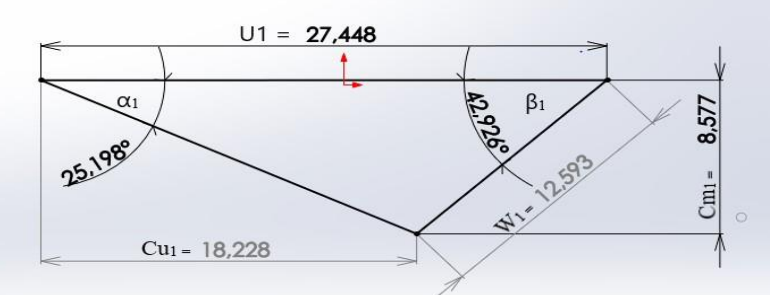

Gambar IV.6 Segitiga kecepatan masuk turbin

Untuk segitiga kecepatan air keluar turbin didapat sebagai berikut:
1) $U_{2}=\frac{U_{21}+U_{2 a}}{2}=\frac{14,410+27,791}{2}=21,1 \mathrm{~m} / \mathrm{s}$
2) $W_{2}=\sqrt{C_{2}{ }^{2}+U_{2}{ }^{2}}=\sqrt{10,293^{2}+21,1^{2}}=23,476 \mathrm{~m} / \mathrm{s}$
3) $\beta_{2}=\operatorname{Cos}^{-1} \frac{U_{2}}{W_{2}}=\operatorname{Cos}^{-1} \frac{21,1}{23,476}=26^{\circ}$

Berikut gambar segitiga kecepatan nya:

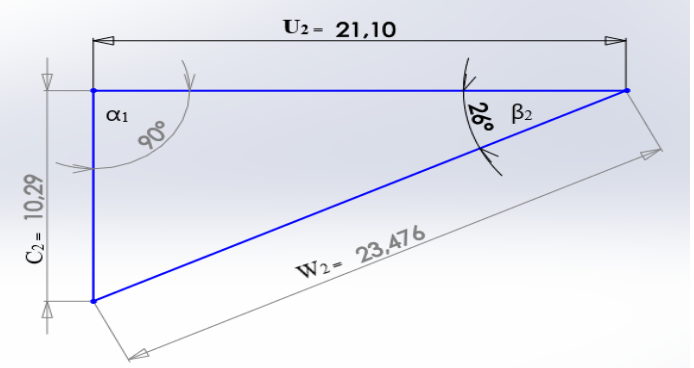

Gambar IV.7 Segitiga kecepatan keluar turbin

c. Runner Turbin

Setelah itu, untuk menghitung runner turbin digunakan persamaan 9 dimana diketahui dari data sebelumnya kecepatan spesifik $\left(\mathrm{N}_{\mathrm{s}}\right)=229,01$ ketinggian efektif $\left(\mathrm{H}_{\mathrm{ef}}\right)=60 \mathrm{~m}$ dan putaran sinkron turbin generator $(\mathrm{n})=1000 \mathrm{rpm}$. Perhitungan diameter ini sangat diperlukan untuk menghitung dimensi-dimensi lainnya seperti spiral casing dan draft tube dimana yang harus dihitung dari runner ini adalah diameter keluaran air dari turbin dengan menggunakan persamaan 8 sampai 12 yang didapat dari buku deSiervo and deLeva dibawah ini:

$$
\begin{aligned}
D_{3} & =(26,2+0,211 \mathrm{Ns}) \frac{\sqrt{h_{e f}}}{n}=(26,2+0,211(229,01)) \frac{\sqrt{60}}{1000} \\
& =0,5772 \mathrm{~m} \\
D_{1} & =\left(0,4+\frac{94,5}{229,01}\right) \times 0,5772=0,4690 \mathrm{~m} \\
D_{2} & =\frac{1}{(0,96+0,000386(229,01))} \times 0,5772=0,5505 \mathrm{~m}
\end{aligned}
$$

Menghitung lebar keluaran dari roda turbin menggunakan persamaan 13 karena kecepatan spesifiknya $\mathrm{N}_{\mathrm{s}}=229,01$ maka:

$\mathrm{H}_{2}=\frac{1}{(3,16-0,0013(229,01))} \times 0,5772=0,2016 \mathrm{~m}$

Setelah mendapatkan dimensi dari diameter runner maka dapat dicari lebar masukan runner turbin dengan menggunakan gambar II.6, dimana untuk putaran spesifik $\mathrm{N}_{\mathrm{s}}=229,01$ didapat nilai perbandingan $\mathrm{B} / \mathrm{D}_{2}=0,26$. Maka didapatkan lebar masukan runner dari persamaan 14:

$\mathrm{B}=0,26 \times 0,5505=0,1431 \mathrm{~m}$

Ukuran-ukuran dari runner digambarkan pada gambar II.6. Material yang digunakan dalam pembuatan runner pada umumnya saat ini dengan menggunakan material Stainless steel (OCr13Ni4Mo). Maka hasil dari perhitungan dimensi runner dapat dilihat pada tebel III.1 sebagai berikut:

Tabel IV.3 Hasil Perhitungan Dimensi Runner Turbin

\begin{tabular}{|l|c|}
\hline \multicolumn{1}{|c|}{ Perhitungan } & Hasil \\
\hline Diameter keluaran runner $\left(\mathrm{D}_{3}\right)$ & $0,5772 \mathrm{~m}$ \\
\hline Diameter masukan runner $\left(\mathrm{D}_{1}\right)$ & $0,4690 \mathrm{~m}$ \\
\hline $\begin{array}{l}\text { Diameter masukan central streamline } \\
\left(\mathrm{D}_{2}\right)\end{array}$ & $0,5502 \mathrm{~m}$ \\
\hline Lebar keluaran runner $\left(\mathrm{H}_{2}\right)$ & $0,2016 \mathrm{~m}$ \\
\hline Lebar masukan runner $\left(\mathrm{H}_{1}=\mathrm{B}\right)$ & $0,1431 \mathrm{~m}$ \\
\hline \multicolumn{2}{|c|}{ Material yang digunakan Stainless steel $($ OCr $13 N i 4 \mathrm{Mo})$} \\
\hline
\end{tabular}

\section{d. Sudu Pengarah}

Parameter yang mempengaruhi perancangan sudu pengarah adalah tinggi efektif $(\mathrm{H})=60 \mathrm{~m}$, debit air $(\mathrm{Q})=2,33 \mathrm{~m}^{3} / \mathrm{dt}$, kecepatan spesifik turbin $(\mathrm{Ns})=229,01$, gravitasi $(\mathrm{g})=9,81 \mathrm{~m}^{2} / \mathrm{s}$ dan kecepatan turbin $(\mathrm{n})=1000 \mathrm{rpm}$. Parameter yang akan dicari pada perancangan sudu pengarah menurut gambar adalah diameter sudu pengarah (D), lebar masukan air pada sudu pengarah (b), panjang sudu pengarah (L), dan jumlah sudu pengarah (Z). Dari persamaan didapatkan nilai parameter yang dicari adalah sebagai berikut:

$$
\begin{aligned}
& \mathrm{D}=\frac{60 \times 1 \times \sqrt{2 \times 9,81 \times 60}}{\pi \times 1000}=0,655 \mathrm{~m} \\
& \mathrm{~b}=\frac{2,33}{\pi \times 0,655 \times 0,15 \times \sqrt{2 \times 9,81 \times 60}}=0,22 \mathrm{~m} \\
& \mathrm{~L} \approx 0,3 \times 0,83=0,196 \mathrm{~m} \\
& \propto=4+0,16\left(229,01\left(1+\frac{229,01}{1000}\right)=49,03^{0}\right.
\end{aligned}
$$

Untuk mencari jumlah sudu pengarah menggunakan tabel dengan nilai kecepatan spesifik turbin $(\mathrm{Ns})=229,01$ dan diameter $0,655 \mathrm{~m}$ maka didapatkan jumlah sudu pengarah sebanyak 12 buah.

Untuk penentuan material sudu pengarah menggunakan Alloy steel $(15 \% \mathrm{Cr}, 0,8 \% \mathrm{Ni}, \mathrm{C}<0,2 \%)$ yang mengacu pada standar DIN G-X12Cr14.

e. Rumah Turbin (Casing Spiral)

Dalam perancangan housing turbin parameter yang mempengaruhi hitungan rancangan adalah tinggi efektif $(H)=60 \mathrm{~m}$, 
debit air $(\mathrm{Q})=2,33 \mathrm{~m}^{3} / \mathrm{dt}$, kecepatan spesifik turbin $(\mathrm{Ns})=229,01$ diameter outlet runner $(\mathrm{D} 3)=0,5572 \mathrm{~m}$. Dengan menggunakan persamaan yang tersedia maka dimensi dari spiral casing sebagai berikut:

$A=\left(1,2-\frac{19,5}{229,01}\right) \times 0,5772=0,6435 \mathrm{~m}$

$B=\left(1,1+\frac{54,8}{229,01}\right) \times 0,5772=0,7731 \mathrm{~m}$

$C=\left(1,32+\frac{49,25}{229,01}\right) \times 0,5772=0,8861 \mathrm{~m}$

$D=\left(1,50+\frac{48,8}{229,01}\right) \times 0,5772=0,9889 \mathrm{~m}$

$E=\left(0,98+\frac{53,60}{229,01}\right) \times 0,5772=0,7008 m$

$\mathrm{F}=\left(1+\frac{131,4}{229,01}\right) \times 0,0,5772=0,9084 \mathrm{~m}$

$\mathrm{G}=\left(0,89+\frac{96,5}{229,01}\right) \times 0,5772=0,7570 \mathrm{~m}$

$\mathrm{H}=\left(0,79+\frac{81,75}{229,01}\right) \times 0,5772=0,6621 \mathrm{~m}$

$I=(0,1+0,00065(229,01)) \times 0,5772=0,1436 \mathrm{~m}$

$\mathrm{L}=(0,88+0,00049(229,01)) \times 0,5772=0,5727 \mathrm{~m}$

$M=(0,60+0,000015(229,01)) \times 0,5772=0,3483 \mathrm{~m}$

Dimana ukuran-ukuran dimensi tersebut mengacu pada gambar II.4 Maka hasil perhitungan dimensi spiral casing dilihat pada tabel IV.4 sebagai berikut:

Tabel IV.4 Hasil Perhitungan Dimensi Spiral Casing

\begin{tabular}{|c|c|c|}
\hline \multicolumn{2}{|c|}{ spiral casing } & Satuan \\
\hline A & 0,6435 & $\mathrm{~m}$ \\
\hline B & 0,7731 & $\mathrm{~m}$ \\
\hline $\mathrm{C}$ & 0,8861 & $\mathrm{~m}$ \\
\hline D & 0,9889 & $\mathrm{~m}$ \\
\hline $\mathrm{E}$ & 0,7008 & $\mathrm{~m}$ \\
\hline $\mathrm{F}$ & 0,9084 & $\mathrm{~m}$ \\
\hline G & 0,7570 & $\mathrm{~m}$ \\
\hline $\mathrm{H}$ & 0,6621 & $\mathrm{~m}$ \\
\hline 1 & 0,1436 & $\mathrm{~m}$ \\
\hline $\mathrm{L}$ & 0,5727 & $\mathrm{~m}$ \\
\hline$M$ & 0,3483 & $\mathrm{~m}$ \\
\hline
\end{tabular}

Untuk penentuan material housing turbine menggunakan besi cor yang mengacu pada standar DIN GG-14.

\section{KESIMPULAN}

Dari hasil penelitian didapatkan bahwa, 1. Head diperoleh sebesar $60 \mathrm{~m}$ dan debit sebesar 2,33 m3/s, 2.Berdasar Head dan debit yang diperoleh, jenis turbin yang digunakan adalah turbin Francis. 3.Hasil rancangan dimensi turbin memiliki diameter keluaran runner (D3) sebesar 0,5772 m, diameter masukan runner (D1) sebesar 0,4690 m, lebar keluaran runner (H2) sebesar 0,2016 $\mathrm{m}$ dan lebar masukan runner (H1) sebesar 0,1431 m. 4.Jumlah sudu pengarah yaitu sebanyak 12 buah dan diameter poros sebesar $95,75 \mathrm{~mm}$. 5.Daya poros yang dihasilkan sebsar 1090,56kW pada putaran $1000 \mathrm{rpm}$.

\section{DAFTAR PUSTAKA}

[1] ..., Rencana Umum Pengusahaan Tenaga Listrik (RUPTL) Indonesia $2016-2025$

[2] Maridjo, dkk. Rancang Bangun Turbin Pelton Mikrohidro, Jurnal Teknik Energi, ISSN: 2089-2527 Vol.6 No.2 Oktober 2016

[3] JICA \& IBEKA, Manual pembuatan Pembangkit Listrik Tenaga Mikrohidro (PLTMH), 2018
[4] Suparyawan dkk, Studi Perencanaan Pembangkit Listrik Mikrohidro di desa Sambangan, Jurnal Teknik Elektro, Vol. 12 No. 2 Juli - Desember 2013

[5] Ikrar Hanggara dkk, Potensi PLTMH di Desa JombokKecamatan Ngantang Kabupaten Malang, Jurnal Reka Buana Volume 2 No 2, Maret 2017 - Agustus 2017

[6] Sri Sukamta dkk., Studi Perencanaan Pembangkit ListrikTenaga Mikro Hidro (PLTMH) Jantur Tabalas Kalimantan Timur, Jurnal Teknik Elektro Vol. 5 No. 2 Juli - Desember 2013

[7] Dietzel, Frit, Turbin, Pompa dan Kompresor, Jakarta: Penerbit Erlangga, 2010

[8] ...Panduan energi terbarukan,2013

[9] ESHA, Guide on How To Develop a Small Hydropower Plant Part 2, 2004 